\title{
OPTIMALISASI CARA EKSTRAKSI SARKOTESTA TERHADAP PROSES DAN HASIL VIABILITAS BENIH PEPAYA (Carica papaya L.)
}

\author{
Rita Hartati ${ }^{1}$ \\ ${ }^{1)}$ Jurusan Teknik Industri, Fakultas Teknik, Universitas Teuku Umar \\ E-mail: cuetrita@gmail.com
}

\begin{abstract}
This study of research is to optimize the way of sarkotesta extract on the process and the result of viability of papaya seed (carica papaya L.) The experimental design used in this study is a complete randomized design (RAL) $4 \times 2$ factorial pattern with 3 replications consisting of two factors, with There were 8 treatment combinations and 24 experimental units. The materials used in this research are papaya seed, cotton cloth, ash, concentrated $\mathrm{H}_{2} \mathrm{SO}_{4}$, and sand. The parameters observed were potential to grow, germination, growth rate and time required $50 \%$ from total germination (T50). The results of this study indicate that the average value of viability and vigor is high in the show on the optimization of the way of extraction of cotton cloth (K1). Viability and vigor of sprouts which are better found in local varieties (V1) than with hybrid varieties (V2). Better interaction optimizing the way extraction of sarcotae is found in hybrid varieties (V2) seeds by extraction of cotton cloth (K1). So it can be concluded that the optimization of sarkotesta extraction method is very significant effect on seed viability include growth potential, germination, growth rate and T50\% sprout total.
\end{abstract}

Keywords: Sarkotesta extraction, viability, papaya seed (Carica papaya L.).

\section{PENDAHULUAN}

Pepaya (carica papaya L.) adalah salah satu jenis tanaman buah-buahan yang daerah penyebarannya berada di daerah tropis. Buah pepaya tergolong buah yang popular dan umumya digemari oleh sebagian besar penduduk dunia. Hal ini disebabkan karena daging buahnya yang lunak dengan warna merah atau kuning, rasanya manis dan menyegarkan serta banyak mengandung air. Tanaman pepaya merupakan tanaman semusim sehingga buah ini dapat tersedia setiap saat [1]. Pepaya memiliki banyak manfaat, yaitu nilai gizi buah yang cukup tinggi karena mengandung banyak provitamin A dan vitamin $C$, juga mineral kalsium, energi dan serat yang tiggi. Disamping itu pepaya juga mengandung Papain, yaitu suatu enzim proteolitik yang terdapat dalam getah pepaya disadap dalam buah muda untuk dimanfaatkan dan dioptimalisasi dalam industri makanan, obat-obatan dan ramuan obat penyembuh pencernaan, Papain juga digunakan untuk perendaman kulit serta menghilangkan perekat pada sutra dan melembutkan wol. Pepaya tergolong buah-buahan yang disukai oleh masyarakat Indonesia dan turut berperan dalam memenuhi kebutuhan keluarga [2]. Buah pepaya merupakan salah satu buah dalam perdagangan yang telah menjadi komoditi ekspor beberapa negara produsen 
di kawasan Asia seperti Malaysia, Thailand, Philippina dan Indonesia. Negara pengimpor pepaya masih didominasi oleh Singapura dan Australia. Indonesia merupakan negara penghasil buah pepaya ke-8 terbesar di dunia. Permintaan kebutuhan pepaya terus meningkat dari beberapa negara Eropa seperti Inggris, Jerman, Perancis, Belanda dan Swedia [3].

Masalah utama pada benih pepaya yaitu terdapat lendir yang menyelimuti biji (sarkotesta) yang dapat menghambat perkecambahan benih [4]. Selama ini penghilangan sarkotesta selalu disarankan dalam penanganan benih pepaya karena sarkotesta dapat menghambat proses perkecambahan. Melalui kegiatan penanganan benih pepaya diharapkan diperoleh benih yang memenuhi mutu genetik, fisik maupun fisiologis karena akhir-akhir ini pengembangan pepaya menurun pada produktivitasnya, salah satunya di akibatkan rendahnya penguasaan teknik penanganan benih secara cepat dan tepat dan juga diakibatkan oleh ketersediaan benih pepaya yang kurang berkualitas dan juga tidak bersertifikat. Kegiatan penanganan benih merupakan rangkaian kegiatan yang dimulai dari optimalisasi produksi benih di lapangan hingga benih akan ditanam kembali. Permasalahan yang dihadapi dalam perbanyakan generatif pepaya adalah karakter benih yang diduga tergolong intermediate [5].

Studi kasus di lapangan, petani pepaya biasanya memperoleh benih dari tanaman terbaik yang ditanam sebelumnya. Cara petani mengoptimalisasi benih tersebut dibersihkan dari lapisan lendir dengan cara merendam benih dalam air 2-3 hari kemudian benih diremas-remas agar sarkotesta terlepas. Benih dijemur dibawah sinar matahari terlebih dahulu sebelum disimpan, karena untuk mengurangi kadar air didalam benih sehingga viabilitas dan vigor benih tetap terjaga.

Mengenai proses optimalisasi benih pepaya masih terbatas sehingga perlu dilakukan berbagai aspek penelitian untuk melengkapinya yaitu upaya pematahan dormansi yang disebabkan oleh lapisan lendir (sarkotesta) yang ada pada permukaan benih dengan cara ekstraksi benih dan pengaruhnya terhadap viabilitas dan vigor.

\section{TINJAUAN PUSTAKA}

\subsection{Botani Tanaman Pepaya}

Pepaya (carica papaya L.) adalah salah satu jenis tanaman buah-buahan yang daerah penyebarannya berada di daerah tropis [6]. Pepaya (Carica papaya L.) merupakan tanaman buah berupa herba dari kelas Dicotyledonae, Ordo Caricales, familia Caricaceae, dan genus Carica tanaman pepaya merupakan tanaman yang beraneka ragam tipe [7]. Sistematika (Taksonomi) tanaman pepaya diklasifikasikan secara lengkap adalah sebagai berikut:

1. Kingdom : Plantae

2. Divisi : Magnoliophyta

3. Kelas : Magnoliopsida

4. Ordo : Brassicales

5. Family : Caricaceae

6. Genus : Carica

7. Species : Carica papaya L.

Buah pepaya bertipe buah berdaging, berbentuk bulat telur-lonjong sampai hampir bulat, rongga tengahnya bersudut lima [8]. Biji berwarna abu-abu sampai hitam dan terbungkus oleh sarkotesta. Biji melekat pada plasenta dalam bakal buah [9]. 


\subsection{Ekstraksi Benih Pepaya}

Ekstraksi benih pepaya dilakukan dengan pemisahan benih dari daging buahnya serta lendir yang menyelimuti kulit benih. Untuk pepaya besar benih yang berasal dari pohon induk yang berumur lebih dua tahun menghasilkan kualitas tanaman dan buah yang terbaik. Benih pepaya umumnya bersifat ortodoks, namun ada benih-benih yang bersifat semi rekalsitran sehingga perlu diatasi dengan metode ekstraksi dan penyimpanan benih yang tepat. Penggunaan kapur tohor $40 \%$ atau abu gosok untuk ekstraksi dan penyimpanan benih merupakan alternatif teknologi sederhana yang dapat digunakan untuk mempertahankan viabilitas [10].

\subsection{Pengaruh Sarkotesta Pada Benih Pepaya}

Benih pepaya diselimuti oleh sarcotesta, suatu lapisan yang mengandung senyawa fenolik, khususnya Phydroxybenzoic acid. Fenol merupakan salah satu antioksidan yang mampu menghambat deteriorasi. Selama ini penghilangan sarcotesta selalu disarankan dalam penanganan benih pepaya karena sarcotesta dapat menghambat proses perkecambahan [11]. Sarkotesta tidak mampu di bersihkan secara manual karena Fenol salah satu antioksidan yang mampu menghambat deteriorasi, dormansi diduga karena pada benih bersarkotesta telah terlanjur melekat kuat pada testa sehingga pencucian secara manual tidak mampu membersihkan sarkotesta secara baik, konsumsi oksigen yang tinggi oleh senyawa fenolik pada kulit benih selama proses perkecambahan dapat membatasi suplai oksigen kedalam embrio. Tinggi rendahnya kandungan air dalam benih memegang peranan yang demikian penting dan berpengaruh besar terhadap viabilitas dan pertumbuhan umum dari dalam benih itu [12].

\subsection{Viabilitas Benih}

Viabilitas benih merupakan daya atau kemampuan untuk hidup yang ditunjukan oleh pertumbuhan atau gejala metabolismenya. Faktor yang mempengaruhi produksi pepaya adalah vigor benih. Vigor sebagai sekumpulan sifat yang dimiliki benih yang menentukan tingkat potensi aktivitas dan performa benih atau lot benih selama perkecambahan dan munculnya kecambah [13]. Pengujian vigor pada suatu benih sangat diperlukan untuk mendapatkan informasi mutu benih. Benih yang tersebar pada petani mempunyai vigor rendah dan vigor tinggi. Tersebarnya benih yang bervigor rendah dan yang tinggi itu dapat mempengaruhi produktivitas tanaman tersebut. Peningkatan vigor tersebut dikenal sebagai invigorasi[14].

\subsection{Syarat Tumbuh Tanaman Pepaya}

a. Iklim

Angin diperlukan untukpenyerbukan bunga. Angin yang tidakterlalu kencang sangat cocok bagi pertumbuhan tanaman. Tanaman pepaya tumbuh subur pada daerah yang memilki curah hujan 1000 - $2000 \mathrm{~mm} / \mathrm{tahun}$. Suhu udara optimum $22-26{ }^{\circ} \mathrm{C}$ dan kelembaban udara sekitar $40 \%$.

b. Tanah

Tanah yang baik untuk tanaman pepaya adalah tanah yang subur dan banyak mengandung humus serta banyak menahan air dan gembur, Derajat keasaman tanah $(\mathrm{pH}$ tanah) yang ideal adalah netral dengan $\mathrm{pH}$ 6-7. Kandungan air dalam tanah merupakan syarat penting dalam kehidupan tanaman ini. Air menggenang dapat mengundang penyakit jamur perusak akar hingga tanaman layu (mati). Apabila kekeringan air tanaman akan kurus, daun, bunga dan buah rontok. Tinggi air yang ideal tidak lebih dalam daripada 50-150 $\mathrm{cm}$ dari permukaan tanah. Pepaya dapat ditanam di dataran rendah sampai ketinggian 700-1000 m dpl. 
c. Hama dan Penyakit

Hama utama tanaman pepaya adalah serangga, jenis serangga yang sering menyerang tanaman pepaya meliputi jenis tungau, kutu, lalat buah, kumbang dan jengat. Organ tanaman pepaya seperti akar, batang, daun dan buah tergolong rentan terhadap penyakit, patogen penyakit tanaman pepaya dapat berupa bakteri cendawan, virus.

\section{METODE PENELITIAN}

\subsection{Alat dan Bahan Penelitian}

Alat yang digunakan dalam penelitian ini yaitu Baskom untuk mengisi media perkecambahan, Cawan Petri, Pinset, handsprayer, Gelas Ukur, Ayakan 12 mesh, Kertas Label dan Alat Tulis Menulis. Bahan yang digunakan yaitu benih pepaya. Benih yang digunakan adalah benih varietas lokal yang bentuk buah oval dan varietas hibrida yaitu pepaya bangkok yang berbentuk buah lonjong. Benih yang digunakan sudah mengalami masak fisiologis, dengan kriteria lebih dari $80 \%$ warna buah telah berubah menjadi kuning merata, buah yang digunakan dengan jumlah 6 buah tiap varietas, untuk masingmasing unit percobaan digunakan sebanyak 25 butir benih. Kain Katun yaitu digunakan untuk mengekstaksi sarkotesta pada benih, abu gosok, $\mathrm{H}_{2} \mathrm{SO}_{4}$ Pekat, dan pasir.

\subsection{Rancangan Penelitian}

Rancangan percobaan yang digunakan dalam penilitian ini yaitu rancangan acak lengkap (RAL) pola faktorial $4 \times 2$ dengan 3 ulangan yang terdiri atas dua faktor, dengan demikian terdapat 8 kombinasi perlakuan dan 24 unit percobaan. setiap unit percobaan terdiri atas 25 butir benih. Adapun faktor-faktor yang diteliti adalah cara ekstraksi sarkotesta $(\mathrm{K})$ yang terdiri atas : $\mathrm{K}_{0}=$ Sarkotesta, $\mathrm{K}_{1}=$ Kain Katun, $\mathrm{K}_{2}=$ Abu Gosok, K3 $=\mathrm{H}_{2} \mathrm{SO}_{4}$ Pekat. Faktor varietas $(\mathrm{V})$ terdiri atas: $\mathrm{V}_{1}=$ Varietas Lokal, $\mathrm{V}_{2}=$ Varietas Hibrida. Susunan Kombinasi Perlakuan Ekstraksi Dengan Varietas Benih Pepaya dapat dilihat pada Tabel 1.

Tabel 1. Susunan Kombinasi Perlakuan Ekstraksi Dengan Varietas Benih Pepaya

\begin{tabular}{cccc}
\hline No. & Kombinasi Perlakuan & Teknik Ekstraksi & Varietas Benih \\
\hline 1. & $\mathrm{~V}_{1} \mathrm{~K}_{\mathrm{O}}$ & Sarkotesta & Lokal \\
2. & $\mathrm{~V}_{1} \mathrm{~K}_{1}$ & Kain Katun & Lokal \\
3. & $\mathrm{~V}_{1} \mathrm{~K}_{2}$ & Abu Gosok & Lokal \\
4. & $\mathrm{~V}_{1} \mathrm{~K}_{3}$ & $\mathrm{H}_{2} \mathrm{SO}_{4}$ Pekat & Lokal \\
5. & $\mathrm{~V}_{2} \mathrm{~K}_{\mathrm{O}}$ & Sarkotesta & Hibrida \\
6. & $\mathrm{~V}_{2} \mathrm{~K}_{1}$ & Kain Katun & Hibrida \\
7. & $\mathrm{~V}_{2} \mathrm{~K}_{2}$ & Abu Gosok & Hibrida \\
8. & $\mathrm{~V}_{2} \mathrm{~K}_{3}$ & $\mathrm{H}_{2} \mathrm{SO}_{4}$ Pekat & Hibrida \\
\hline
\end{tabular}

\section{HASIL DAN PEMBAHASAN}

\subsection{Pengaruh Cara Ekstraksi Sarkotesta}

Optimalisasi ekstraksi sarkotesta sangat nyata pengaruhnya terhadap proses dan hasil viabilitas benih pepaya yaitu potensi tumbuh, daya berkecambah, kecepatan tumbuh dan waktu yang dibutuhkan $50 \%$ dari perkecambahan total (T50) dilihat pada Tabel 2. 
Tabel 2. Rata-rata potensi tumbuh, daya berkecambah, kecepatan tumbuh dan waktu yang di butuhkan $50 \%$ perkecambahan total (T50) pada berbagai perlakuan cara optimalisasi ekstraksi sarkotesta.

\begin{tabular}{lcccc}
\hline \multicolumn{1}{c}{ Ekstraksi } & $\begin{array}{c}\mathrm{PT} \\
(\%) / \operatorname{Arc} \sin \\
\sqrt{ } \%\end{array}$ & $\begin{array}{c}\mathrm{DB} \\
(\%) / \mathrm{Arc} \\
\sin \sqrt{ } \%\end{array}$ & $\begin{array}{c}\mathrm{KcT} \\
(\%) / \operatorname{Arc} \\
\sin \sqrt{ } \%\end{array}$ & $\begin{array}{c}\mathrm{T}_{50} \\
(\%) / \\
\mathrm{Arc} \mathrm{sin} \\
\sqrt{ } \%\end{array}$ \\
\hline Sarkotesta & $50.39 \mathrm{~b}$ & $47.05 \mathrm{~b}$ & $13.93 \mathrm{~b}$ & $13.73 \mathrm{~b}$ \\
$\left(\mathrm{~K}_{0}\right)$ & $(58.00)$ & $(52.66)$ & $(6.13)$ & $(5.65)$ \\
Kain Katun & $50.58 \mathrm{~b}$ & $51.52 \mathrm{~b}$ & $15.44 \mathrm{~b}$ & $14.20 \mathrm{~b}$ \\
$\left(\mathrm{~K}_{1}\right)$ & $(58.00)$ & $(60.00)$ & $(7.17)$ & $(6.06)$ \\
$\mathrm{Abu}$ Gosok & $52.44 \mathrm{~b}$ & $47.08 \mathrm{~b}$ & $14.61 \mathrm{~b}$ & $13.98 \mathrm{~b}$ \\
$\left(\mathrm{~K}_{2}\right)$ & $(61.33)$ & $(52.66)$ & $(6.61)$ & $(5.87)$ \\
$\mathrm{H}_{2} \mathrm{SO}_{4}$ Pekat & $5.74 \mathrm{a}$ & $5.74 \mathrm{a}$ & $5.74 \mathrm{a}$ & $5.74 \mathrm{a}$ \\
$\left(\mathrm{K}_{3}\right)$ & $(0.00)$ & $(0.00)$ & $(0.00)$ & $(0.00)$ \\
$\mathrm{BNJ}_{0.05}$ & 20.98 & 15.59 & 3.93 & 1.30 \\
\hline
\end{tabular}

Keterangan: Angka yang diikuti oleh huruf yang sama pada kolom yang sama tidak berbeda nyata pada uji BNJ 5\%

(\%) Angka sebelum transformasi $\operatorname{Arc} \operatorname{Sin} \sqrt{\mathrm{x}}$

Dari tabel 2 dapat dilihat bahwa analisis viabilitas benih pepaya yang diamati berdasarkan potensi tumbuh, daya berkecambah, kecepatan tumbuh dan waktu yang dibutuhkan untuk mencapai $50 \%$ dari perkecambahan total (T50), hasil optimalisasi ekstraksi menggunakan abu gosok $\left(\mathrm{K}_{2}\right)$ dan kain katun $\left(\mathrm{K}_{1}\right)$ tidak ada perbedaan dibandingkan dengan benih yang masih utuh sarkotesta $\left(\mathrm{K}_{\mathrm{o}}\right)$. Perlakuan optimalisasi ekstraksi menggunakan $\mathrm{H}_{2} \mathrm{SO}_{4}$ pekat menyebabkan semua benih menjadi mati, sehingga tidak ada benih yang mampu berkecambah. Terdapat kecendrungan nilai viabilitas benih lebih tinggi dibandingkan dengan benih tanpa ekstraksi sarkotesta (sarkotesta utuh). Benih pepaya menunjukkan adanya senyawa fenolik pada sarkotesta. Kandungan senyawa fenolik, khususnya $p$-hydroxybenzoic acid, berada pada konsentrasi yang secara nyata menyebabkan penghambatan perkecambahan. Dormansi diduga karena pada benih tersebut sarkotesta telah terlanjur melekat kuat pada testa sehingga pencucian secara manual tidak mampu membersihkan sarkotesta dengan baik [15].

Nilai rata-rata viabilitas dan vigor yang tinggi di tunjukan pada cara ekstraksi kain katun $\left(\mathrm{K}_{1}\right)$. Hal ini di sebabkan ekstraksi benih dengan menggunakan kain katun dapat memberikan hasil yang lebih baik di bandingkan dengan cara ekstraksi abu gosok dan $\mathrm{H} 2 \mathrm{SO} 4$ pekat, ini menunjukan bahwa pada ekstraksi kain katun dapat mempengaruhi perkecambahan benih pepaya serta proses menghilangkan sarkotesta terkupas dengan baik pada kulit benih yang dapat mempengaruhi viabilitas dan vigor benih pepaya. Cara ekstraksi yang berbeda menghasilkan perbedaan nilai viabilitas dan vigor benih pepaya. Viabilitas benih merupakan daya hidup benih yang dapat diindikasikan oleh berbagai tolak ukur, baik tolak ukur yang secara langsung dengan menilai pertumbuhan benih maupun yang secara tidak lansung dengan menilai gejala metabolismenya [16]. Rata-rata potensi tumbuh, daya berkecambah, kecepatan tumbuh dan waktu yang dibutuhkan $50 \%$ dari perkecambahan total (T50) dari kedua varietas benih pepaya yang dicobakan dapat dilihat pada tabel 3 . 
Tabel 3. Rata-rata potensi tumbuh, daya kecambah, kecepatan tumbuh dan waktu yang dibutuhkan $50 \%$ dari perkecambahan total (T50) pada varietas benih pepaya $(\%)$

\begin{tabular}{ccccc}
\hline & $\mathrm{PT}$ & $\mathrm{DB}$ & $\mathrm{KcT}$ & $\mathrm{T}_{50}$ \\
& $(\%) /$ & $(\%) /$ & $(\%) /$ & $(\%) /$ \\
Varietas Benih & $\operatorname{Arc}$ & $\mathrm{Arc}$ & $\mathrm{Arc}$ & $\mathrm{Arc}$ \\
& $\sin \sqrt{ } \%$ & $\sin \sqrt{ } \%$ & $\sin \sqrt{ } \%$ & $\sin \sqrt{ } \%$ \\
\hline Varietas Lokal & 43.05 & 39.65 & 13.28 & 11.87 \\
$\left(\mathrm{~V}_{1}\right)$ & $(49.66)$ & $(44.33)$ & $(5.73)$ & $(4.36)$ \\
Varietas Hibrida & 36.53 & 36.05 & 11.58 & 11.95 \\
$\left(\mathrm{~V}_{2}\right)$ & $(39.00)$ & $(38.33)$ & $(4.22)$ & $(4.43)$ \\
\hline
\end{tabular}

Keterangan: (\%) Angka sebelum transformasi Arc Sin $\sqrt{\mathrm{x}}$

Tabel 3 menunjukan potensi tumbuh, daya berkecambah, kecepatan tumbuh dan waktu yang dibutuhkan $50 \%$ dari perkecambahan total (T50) dari kedua varietas tidak berbeda. Namun terdapat kecendrungan bahwa nilai viabilitas dari varietas lokal $\left(\mathrm{V}_{1}\right)$ lebih tinggi dibandingkan dengan varietas hibrida $\left(\mathrm{V}_{2}\right)$. Varietas benih pepaya yang digunakan tidak berpengaruh nyata karena buah mengalami masak fisiologis yang sama antara kedua varietas tanpa adanya penyimpanan buah dan pemeraman. Benih yang telah masak fisiologis telah mempunyai cadangan makanan sempurna sehingga dapat menunjang pertumbuhan kecambah, tingkat kemasakan benih dapat dicirikan dari tingkat kemasakan buahnya. Ini diduga bahwa pengaruh varietas benih pepaya mampu meningkatkan sifat fisiologis dan biokimia benih sehingga dapat meningkatkan viabilitas dan vigor benih [17].

\subsubsection{Interaksi}

Terdapat interaksi yang sangat nyata antara varietas benih dengan cara ekstraksi terhadap daya kecambah yaitu tidak berpengaruh nyata terhadap potensi tumbuh dan kecepatan tumbuh, waktu yang dibutuhkan $50 \%$ dari perkecambahan total (T50). Ratarata daya kecambah pada beberapa varietas benih dan perlakuan cara ekstraksi setelah di uji dengan BNJ0.05 dapat dilihat pada Tabel 4.

Tabel 4. Rata-rata daya berkecambah beberapa varietas benih akibat perlakuan cara ekstraksi (\%)

\begin{tabular}{|c|c|c|c|c|}
\hline \multirow[b]{2}{*}{ Varietas } & \multicolumn{4}{|c|}{ Teknik Ekstraksi } \\
\hline & $\begin{array}{c}\text { Sarkotesta } \\
\left(\mathrm{K}_{0}\right) \\
(\%) / \operatorname{Arc} \\
\sin \sqrt{ } \%\end{array}$ & $\begin{array}{c}\text { Kain } \\
\text { Katun } \\
\left(\mathrm{K}_{1}\right) \\
(\%) / \operatorname{Arc} \\
\sin \sqrt{ } \%\end{array}$ & $\begin{array}{c}\text { Abu } \\
\text { Gosok } \\
\left(\mathrm{K}_{2}\right) \\
(\%) / \operatorname{Arc} \\
\sin \sqrt{ } \%\end{array}$ & $\begin{array}{c}\mathrm{H}_{2} \mathrm{SO}_{4} \\
\text { Pekat } \\
\left(\mathrm{K}_{3}\right) \\
(\%) / \mathrm{Arc} \\
\sin \sqrt{ } \%\end{array}$ \\
\hline $\begin{array}{l}\text { Varietas Lokal } \\
\left(\mathrm{V}_{1}\right) \\
\text { Varietas Hibrida } \\
\left(\mathrm{V}_{2}\right) \\
\mathrm{BNJ}_{0.05}=26.70\end{array}$ & $\begin{array}{l}54.88 \mathrm{~b} \\
(65.33) \\
39.21 \mathrm{~b} \\
(40.00)\end{array}$ & $\begin{array}{l}40.65 \mathrm{~b} \\
(42.66) \\
62.39 \mathrm{~b} \\
(77.33)\end{array}$ & $\begin{array}{l}57.31 \mathrm{~b} \\
(69.33) \\
36.85 \mathrm{~b} \\
(36.00)\end{array}$ & $\begin{array}{l}5.74 \mathrm{a} \\
(0.00) \\
5.74 \mathrm{a} \\
(0.00)\end{array}$ \\
\hline
\end{tabular}

Keterangan: Angka yang diikuti oleh huruf yang sama menunjukkan berbeda tidak nyata pada uji BNJ 5\%

(\%) Angka sebelum transformasi $\operatorname{Arc} \operatorname{Sin} \sqrt{\mathrm{x}}$ 
Tabel 4 memperlihatkan bahwa nilai viabilitas benih pepaya yang diamati berdasarkan daya berkecambah, dari benih yang diekstraksi dengan kain katun (K1) dan abu gosok (K2) maupun benih tanpa ekstraksi nilainya tidak berbeda. Namun nilai viabilitas menjadi berbeda dan menurun secara nyata ketika benih diekstraksi dengan menggunakan $\mathrm{H} 2 \mathrm{SO} 4$ pekat (K3). Benih yang berkualitas adalah yang murni varietas nya, tinggi daya kecambahnya dan mampu memberikan produksi yang maksimal, karena itu pengunaan benih yang berkualitas merupakan cara yang paling mendasar dan termurah diantara cara-cara yang lain untuk produksi tanaman. keturunan nyatoh[18]. Faktor penyebab terjadinya variasi antarpohon adalah perbedaan genetik antarpohon, perbedaan lingkungan tempat pohon itu tumbuh, dan interaksi antara keduanya [19].

\section{KESIMPULAN}

Adapun kesimpulan dari penelitian ini adalah:

1. Optimalisasi cara ekstraksi sarkotesta berpengaruh sangat nyata terhadap proses dan hasil viabilitas benih yang meliputi potensi tumbuh, daya berkecambah, kecepatan tumbuh dan T50 \% kecambah total. Viabilitas yang lebih baik dijumpai pada cara ekstraksi kain katun.

2. Terdapat interaksi yang sangat nyata terhadap daya berkecambah dan waktu yang dibutuhkan untuk mencapai $50 \%$ dari perkecambahan total (T50).

3. Interaksi yang lebih baik optimalisasi cara ekstraksi sarkotesta dijumpai pada benih varietas hibrida (V2) dengan cara ekstraksi kain katun (K1).

4. Nilai viabilitas menjadi berbeda dan menurun secara nyata ketika benih diekstraksi dengan menggunakan $\mathrm{H} 2 \mathrm{SO} 4$ pekat.

\section{SARAN}

Adapun saran dari penelitian yang sudah dilakukan yaitu perlu dilakukan penelitian lebih lanjut terhadap cara ekstraksi sarkotesta dengan lebih memperhatikan upaya untuk menghilangkan efek penghambat perkecambahan benih pada berbagai varietas dengan teknik ekstraksi yang mampu meningkatkan perkecambahan yang maksimal.

\section{DAFTAR PUSTAKA}

[1] Barus, A dan Syukri. 2008. Agroekoteknologi Tanaman Buah-Buahan. US Press. Medan.

[2] Kalie, 2003. Bertanam Pepaya. Penebar Swadaya. Jakarta.47 hal.

[3 Purba, 2005. Pengaruh Pemangkasan Pohon dan Letak Benih terhadap Peningkatkan Produksi dan Mutu Benih Pepaya (Carica papaya L.) Tesis. Program Studi Agronomi IPB. Bogor.

[4] Kalie, M.B.2004. Bertanam Pepaya. Penebar Swadaya. Jakarta. 120 hal.

[5] Wood, C.B. Hugh W.P. and Dilip Amritphale. 2000. Desiccation-induce dormancy in papaya (Carica papaya L.). seed is alleviated by heat shock. 
[6] Sebayang, A., Nissa, C., Rahmawati, N. 2014. Pengaruh pemeraman, pengeringan, dan keberadaan sarcotesta Terhadap perkecambahan benih pepaya (carica papaya 1.) Varietas callina. Jurnal Online Agroteknologi, 2 (3): 1133-1141.

[7] Wills, 1990. Taksonomi pepaya. (Carica papaya L.) Jakarta. $123 \mathrm{hlm}$.

[8] Villegas, V, N. 1997. Bentuk buah pepaya (Carica papaya L.) hal 125-131

[9] Nakasone, H.Y. and R.E Paul. 1998. Tropikal Fruits. Crop Production Science in Horticulture. C.A.B.Int.4 45 p.

[10] Baki dan Anderson, 1972. Pengaruh Kosentrasi Rootone F dan Lama Perendaman Terhadap Viabilitas Benih Jagung (Zea mays L.) Kadar luasa. Skripsi. Fakultas Pertanian Universitas Syiah Kuala. 40 hlm

[11] Sari, M. 2004. Pengaruh Sarkotesta dan Kadar Air Benih Terhadap Viabilitas, Kandungan Total Fenol dan Daya Simpan Benih Pepaya (Carica papaya L.) Skripsi. Jurusan Budidaya Pertanian. IPB. Bogor.

[12] Kartasapoetra. 2003. Teknologi Benih. Pengolahan Benih dan Tuntutan Praktikum. Rieneka Cipta. Jakarta.

[13] Murniati, E, M. Sari dan E. Fatimah. 2008. Pengaruh Pemeraman Buah dan Periode Simpan Terhadap Viabilitas Benih Pepaya (Carica papaya L.). Jurnal: Bul. Agron. (36) (2) 139.

[14] Novita, F.C.S. 2014. Viabilitas Benih Melon (Cucumis Melo L.) pada Kondisi Optimum dan Sub-Optimum Setelah Diberi Perlakuan Invigorasi. Jurnal Agrohorti 2 (1): 59-65.

[15] Chow, Y.J., C.H. Lin. 1991. p-Hydroxybenzoic acid as the major phenolic germination inhibitor of papaya seed. Seed Sci. and Technol. $174 \mathrm{p}$.

[16] Sadjad. S. 1994. Dari Benih Kepada Benih. Grasindo, Jakarta. 143 hlm.

[17] Copeland, Mc Donald. 2001. Principles of seed science and technologi. 4 th edition. Kluwer Academic Publishers. London. $42 \mathrm{sp}$.

[18] Mugnisjah, W. Q. A. Setiawan, Sumanto dan c. Santiva. 1994. Panduan Praktikum dan Penilitian Bidang Ilmu dan Teknologi Benih. PT Raja Gravindo Persada, Jakarta. $40 \mathrm{hlm}$.

[19] Halawena, J. 2015. Variasi Genetik Pertumbuhan Tanaman Uji Keturunan Nyatoh (Pala Quium Optusi Folium) Umur 1.5 Tahun di Hutan Penelitian Batuangus Sulawesi Utara. Jurnal Pros Sem Nas Masy Biodiv Indon. 1 (4): 819-823. 